\title{
TWO NEW SPECIES OF GENUS EPACRIS (EPACRIDACEAE) FROM TASMANIA
}

\author{
by R.K. Crowden
}

(with one text-figure)

CROWDEN, R.K., 1986 (12:ix): Two new species of genus Epacris (Epacridaceae) from Tasmania. Pap. Proc. R. Soc. Tasm. 120: 17-19. https://doi.org/10.26749/rstpp.120.17 ISSN 0080-4703. Botany Department, University of Tasmania, Hobart, Australia 7000.

Epacris apsleyensis R.K. Crowden, sp.nov. and Epacris grandis R.K. Crowden, sp.nov. are described. Notes on the distribution, habitat and affinities of both species are included.

Key Words: Epacris, Epacridaceae, Tasmania.

\section{INTRODUCTION}

Two newendemicspecies of the genus Epacris from the east coast region of Tasmania have been discovered and are described below. They are illustrated in figure 1.

\section{EPACRIS APSLEYENSIS \\ R.K. CROWDEN, SP.NOV.}

Frutex erectus usque ad $1.5 \mathrm{~m}$, plerumque minus quam $1 \mathrm{~m}$. Folia lanceolata vel elliptice lanceolata, 5-9 $\mathrm{mm}$ longa, 2-3 $\mathrm{mm}$ lata, in supera parte reflexa, apice acuto, breviter mucronato, costa carinata. Flores albi, subsessiles, pro parte majore ad extremitates ramulorum aggregati. Bracteae ovatae glabrae. Sepala ovato-lanceolata, a pice acuto. Tubus corollae ca mpanulatus, $2-3 \mathrm{~mm}$ longus, glaber. Antherae minus quam $1 \mathrm{~mm}$ longae, subsessiles. Stylus quam tubus brevior, prope centrum bulbosus. Holotypus Rosedale Rd, at Apsley River crossing, near Bicheno, Tasmania; Crowden 8404-01, 23.iv.1984; ( HO 95100).

An erect sparsely branched shrub, sometimes reaching $1.5 \mathrm{~m}$ in height but mostly less than $1 \mathrm{~m}$. Young stems smooth, red-brown, with sparse to dense hairs. Leaves alternate, spreading and scattered on older branches, 5-9 $\mathrm{mm}$ long, 2-3 mm wide; petiole short (ca. $1 \mathrm{~mm}$ ) semi-appressed to stem, both surfaces concave, the upper surface pubescent with sparse hairs extending onto the base of the lamina, lower surface glabrous; la mina jointed with petiole, lanceolate-elliptic, reflexed in upper part, upper surface glabrescent, lower surface glabrous, apex acute, tip a short mucro, barely pungent, base obtuse, margin scabrous, midrib keeled and conspicuous, other veins indistinct.

Flowers white, erect, sub-sessile, solitary in leaf axils, mostly clustered towards branch tips, but with a tendency to spread down branches in compact leafy spikes; bracts white, streaked with pink, ovate, glabrous, slightly keeled near tip, a pex acute, margin ciliolate near tip; sepals white, streaked with pink, ovate-lanceolate, 3-4 mm long, a pex acuminate, margin ciliolate near tip. Corolla tube white, +/-campanulate, 2-3 $\mathrm{mm}$ long, ca. 3 $\mathrm{mm}$ wide at throat, glabrous; lobes genicula te near tube, the distal segments flat or slightly wavy, 3-4 $\mathrm{mm}$ long, 2-3 $\mathrm{mm}$ wide overlapping at joints, apex obtuse. Anthers brown, less than $1 \mathrm{~mm}$ long, enclosed within the corolla tube or tips barely reaching the plane of joints, sub-sessile on short free filament segments. Ovary rounded, smooth, glabrous, 5-locular. Style ca. 1.0-1.5 mm long, usually slightly bulbous near centre, glabrous; stigma clavate, below base of anthers. Nectary scales triangular, a pices truncate, ca. $1 / 3$ length of ovary.

\section{Distribution and Ecology}

Epacris apsleyensis has a restricted distribution. It is known only from two locations, both of which are adjacent to the Apsley River. It occurs on old river terrace sediments over dolerite bed rock in dry sclerophyll communities (low, open forest), dominated by Eucalyptus amygdalina and with a relatively dense understorey including Callitris oblonga, Banksia marginata and Helichrysum costatifructum.

\section{Specimens Examined (all in $\mathrm{HO}$ )}

Rosedale Rd, near Bicheno, Crowden 830703, 10.vii.1983. Apsley River bridge on Rosedale $\mathrm{Rd}$, near Bicheno, Crowden 8404-01, 23.iv.1984. Apsley River floodplain at Lilla Villa. Crowden 8509-07, 10.ix.1985. 


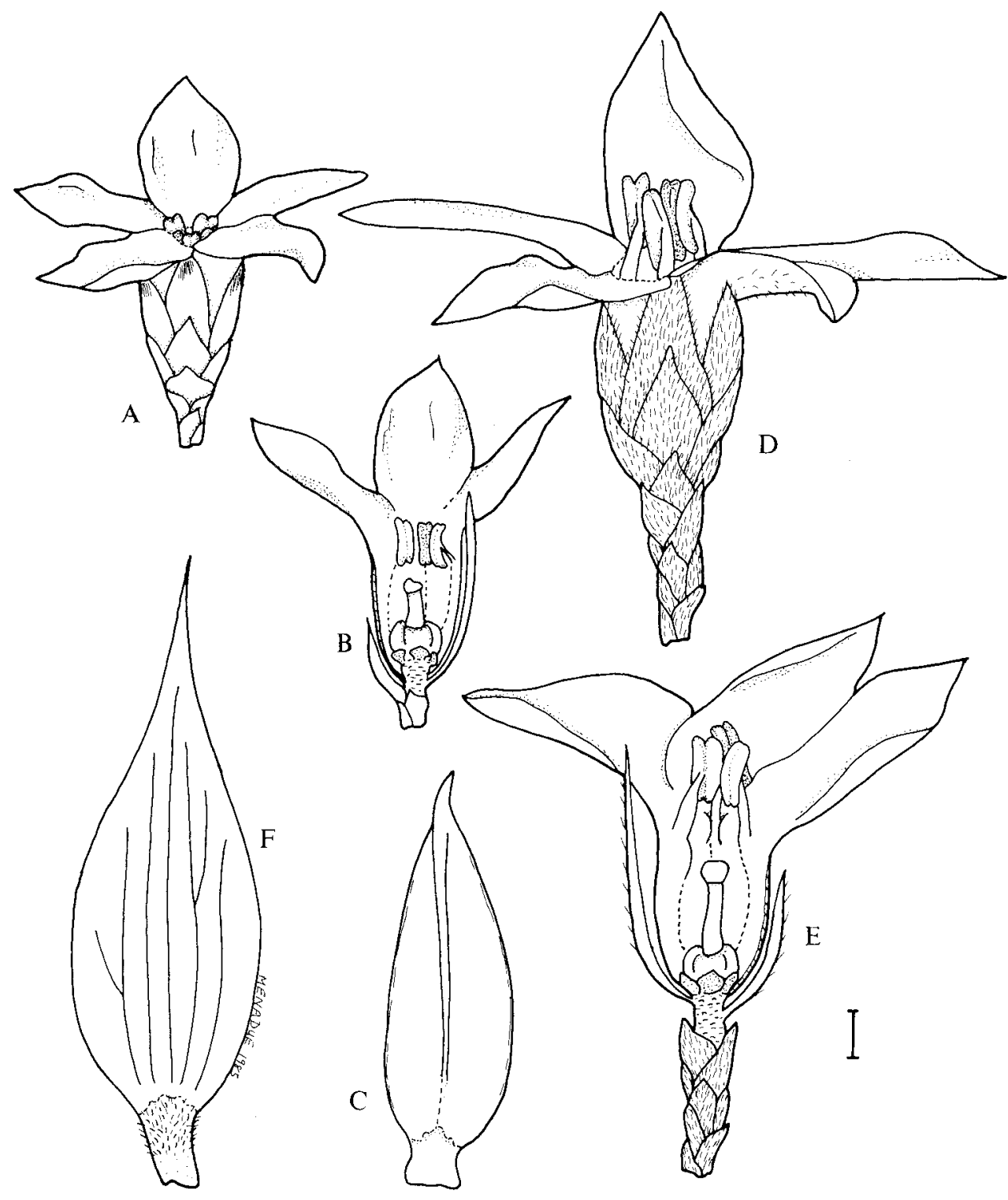

FIG.1 - Epacris apsleyensis: $a-$ whole flower, $b$-halfflower, $c$ - leaf (abaxial view). E. grandis:

$d$-whole flower, e- halfflower, $f$ - leaf (abaxial view). Scale bar $=I \mathrm{~mm}$.

\section{Comments}

Epacris apsleyensis may be confused with $E$. tasmanica W.M. Curtis, which occurs extensively in lowland areas south of the Apsley River and in the Apsley River gorge. It differs from E. tasmanica mainly in floral morphology, having anthers (both exserted beyond the tube in E. tasmanica), and in the smaller size of the flowers. E. apsleyensis flowers throughout winter. The epithet "apsleyensis" refers to its locality. 


\section{EPACRIS GRANDIS \\ R.K. CROWDEN, SP.NOV.}

Frutex erectus saepe $2 \mathrm{~m}$ excedens. Folia lanceolata vel late lanceolata, 10-15 mm longa, 3-4 $\mathrm{mm}$ lata; lamina plana vel parum prope basin concava apice acuto, aristato. Flores albi, pedicellati, numerosi, in spicis longis. Bracteae ovatae, pubescentes. Sepala lanceolata, hirsuta, apicibus acutis. Tubus corollae campanulatus, $4-5 \mathrm{~mm}$ longus, pilis sparsis extra ad paginam inferam loborum extensis. Antherae magnae, $1.5 \mathrm{~mm}$ longae, exsertae. Stylus quam brevior tubus, prope basin parum bulbosus. Holotypus, headwaters of Blindburn Creek, near Bicheno, Tasmania R.K. Crowden 8411-07, 16.xi.1984 (HO 95101); isotypes AD, CANB, MEL, NSW.

An erect shrub up to $2.5 \mathrm{~m}$ in height. Young stems smooth, red to red-browm, pubescent. Leaves alternate, spreading and evenly spaced on older parts of the stem, $10-15 \mathrm{~mm}$ long, 3-4 $\mathrm{mm}$ wide; petiole short, l-2 mm long, semi-appressed to stem, upper surface concave, glabrescent, lower surface concave and glabrous; lamina lanceolate to broadly lanceolate, $+/$-jointed with petiole, flat or slightly concave near base, sometimes with a slightly inflexed tip, both surfaces glabrous, apex acute, tip aristate and pungent, base obtuse, margin slightly scabrous, midrib not keeled (or slightly so near tip), 5 or more veins conspicuous on abaxial surface. Flowers white, erect on distinct pedicel ca. $4 \mathrm{~mm}$ long, solitary in leaf axils extending down 1-year branches in long leafy spikes; bracts ovate, hirsute, apex acute, margin ciliate; sepals white, pink streaked, lanceolate, 4-6 mm long, $1-1.5 \mathrm{~mm}$ wide, hirsute, apex acute, margin ciliate. Corolla tube + -campanulate, 4-5 $\mathrm{mm}$ long ca. $4 \mathrm{~mm}$ wide at throat, white, glabrous internally, sparse hairs on outer surface near throat extending onto undersurface of lobes; lobes geniculate above tube, the distal segments flat, 5-6 mm long, 3-4 mm wide, overlapping at the joints, apex obtuse. Anthers brown, large ca. $1.5 \mathrm{~mm}$ long, $0.5 \mathrm{~mm}$ wide, exserted beyond plane of jointed lobes on free filament segments ca. $2 \mathrm{~mm}$ long. Ovary rounded, smooth, glabrous, 5-locular. Style shorter than the tube, ca. $2 \mathrm{~mm}$ long, glabrous, slightly bulbous near base; stigma cla vate. Nectary scales triangular with rounded apices ca. 1/3 length of ovary.

\section{Distribution and Ecology}

Epacris grandis has been collected from several locations west and northwest of Bicheno. It grows on shallow podzolic soil in dry, stony (dolerite) areas, often with surface water. The community is a dry sclerophyll forest, dominated by Eucalyptus obliqua, the understorey including Banksia marginata, Leptospermum grandiflorum, Bedfordia salicina, Boronia pilosa and Xanthorrhea australis. A small isolated group of plants forms a riverine community on alluvial soil on the lower Douglas River.

\section{Specimens Examined (all in $\mathrm{HO}$ )}

Summit Nichols Cap, Moscal 178, 20.iii.1980; Blindburn Creek, Moscal 343, 5.vi.1980; lower reach of Douglas River gorge, Crowden 8409-20, 11.ix.1984; headwaters of Blindburn Creek, Crowden 8411-07, 16.xi.1984.

\section{Comments}

Epacris grandis is an impressive plant, frequently exceeding in height most of the cohabiting understorey species. It flowers in NovemberDecember. It appears to be most closely related to E. marginata (which occurs on similar exposed dolerite platforms and boulder areas at or near sea-level on Tasman Peninsula and Maria Island), and $E$. heteronema. It is distinguished from $E$. marginata by the vestiture of the bracts, sepals and corolla, and in the more open leaf and inflorescence arrangement. E. grandis also lacks the distinctive hyaline leaf margin of E. marginata. E. grandis resembles $E$. heteronema more closely in its vegetative characteristics, but it is readily separated on floral characters. E. heteronema has anthers enclosed within the corolla tube; the bracts, sepals and corolla are glabrous, and the flowers are usually clustered near the tips of the branches. The epithet "grandis" $d$ raws attention to the impressive stature of the plant.

\section{ACKNOWLEDGEMENTS}

The author acknowledges with thanks, the assistance of Dr A. Orchard with the Latin descriptions, and of Yvonne Menadue for the drawings.

(accepted May 23, 1986) 